\title{
Outbreak of Shigella sonnei infection in Terme City, Turkey, September 2012
}

\section{Terme ilçesinde Shigella sonnei enfeksiyonu salgını, Türkiye, Eylül 2012}

\author{
Selmur TOPAL ${ }^{1}$, Hüseyin ÇELIK² ${ }^{2}$ Şenol YILMAZ³ ${ }^{3}$, Erdinç ÖZOĞLU ${ }^{4}$, Okan KARAOĞLANOĞLU ${ }^{4}$, \\ Fehminaz TEMEL ${ }^{1}$, Hülya ȘiRiN ${ }^{5}$
}

\section{ABSTRACT}

Objective: Waterborne outbreaks occur in Turkey every year; however, few have been thoroughly investigated. On 24 September 2012, an increase in gastroenteritis cases in Terme City, Samsun Province was reported to the Public Health Institution of Turkey. We investigated this outbreak to determine its source and mode of transmission, and to recommend control measures.

Methods: A matched case control investigation was conducted. A probable case had onset of diarrhoea ( $\geq 2$ / day) and vomiting plus $\geq 2$ of the following symptoms in a Terme City resident: abdominal pain, nausea, perceived fever. In the study, we compared exposures during 15-24 September, of probable cases and 1:1 matched neighbourhood control-persons. We took stool samples of 33 cases to identify the agent and for bacteriological, viral and parasitological tests. We inspected the water sources, water distribution system and tanks for possible cause of contamination and collected water samples.

Results: We identified 4050 hospital admissions with gastroenteritis-related ICD codes from acute gastroenteritis surveillance data. The attack rate was

\section{ÖZET}

Amaç: Türkiye'de her yıl su kaynaklı akut gastroenterit salgınları görülmekle birlikte bunların sadece bazıları ayrıntılı olarak araștırılmaktadır. Samsun Halk Sağlığı Müdürlüğü, 24 Eylül 2012 tarihinde, Terme ilçesinde akut gastroenterit vakalarında artış olduğunu Türkiye Halk Sağlığı Kurumu'na bildirmiștir. Bu çalıșmada, salgının kaynağını ve bulaș yolunu tespit etmek ve salgın ile ilgili kontrol önlemlerini almak amacı ile yapılmıștır.

Yöntem: Eșleștirilmiş vaka kontrol çalıșması yapılmıștır. Araștırmada olası vaka Terme ilçesinde ikamet eden, günde iki ve daha fazla ishal, kusma veya karın ağrısı, bulantı, ateș ve diğer semptomlardan iki ve daha fazlasına sahip olan kiși olarak tanımlanmıștır. Çalıșmada, 15-24 Eylül tarihleri arasında hastaneye bașvuran olası vakalar ve bunların 1.1 eșleștirme ile komșularından seçilen kontroller maruziyet açısından karșılaștırılmıștır. Etkenin tespit edilmesi için hastaneye başvuran vakaların 33'ünden gaita numunesi alınmış, mikrobiyolojik, viral ve parazitolojik inceleme yapılmıștır. Salgına neden olduğu düșünülen kontaminasyonun tespit edilmesi amacı ile su kaynakları, deposu ve su șebeke sistemi de incelenmiș ve su örnekleri alınmıștır.

Bulgular: Akut barsak enfeksiyonu sürveyans

' Public Health Institution of Turkey, Early Warning and Response and Field Epidemiology Department, Ankara

${ }^{2}$ Public Health Institution of Turkey, Communicable Diseases Department, Ankara

${ }^{3}$ Public Health Institution of Turkey, Environmental Health Department, Ankara

${ }^{4}$ Public Health Institution of Turkey, Samsun Provincial Health Directorate, Samsun

${ }^{5}$ Public Health Institution of Turkey, Office of the Presidency, Ankara

İletişim / Corresponding Author : Selmur TOPAL

Sağlık Mahallesi Adnan Saygun Cad. Refik Saydam Yerleşkesi No:55 06100 Ankara - Türkiye

Tel : +905426746099 E-posta/E-mail : selmurtopal@yahoo.com

Geliş Tarihi / Received : 10.04 .2018 Kabul Tarihi / Accepted : 20.10 .2018

DOI ID : 10.5505/TurkHijyen.2018.90277

Topal S, Çelik H, Yılmaz Ș, Özoğlu E, Karaoğlanoğlu O, Temel F, Șirin H. Outbreak of Shigella sonnei infection in Terme City, Turkey, September 2012.

Turk Hij Den Biyol Derg, 2019; 76(2): 141-148 
9.2\% in this outbreak investigation, of 112 probable cases, 65\% had drank unboiled tap-water during 15-24 September, compared to $50 \%$ of 112 control-persons (ORadj=1.9; 95\% Cl: 1.1-3.5); conversely, 39\% of casepatients and $54 \%$ of control-persons had drank bottled water (ORadj=0.51, 95\% Cl: 0.29-0.90). Of 33 stool specimens collected, 27 were culture-positive for S. sonnei; of 52 water samples collected at various distribution points, 18 had total coliform (range: 47500) and four had Escherichia coli (range: 5-20). Environmental investigation revealed a damaged waterpipe nearby the water tank.

Conclusion: This large Shigella sonnei outbreak was caused by drinking contaminated tap-water. We recommended thorough inspection and repair of water treatment system.

Key Words: Shigella sonnei, outbreaks, drinking water, case-control studies verilerinin incelenmesinde hastaneye 4050 gastroenterit tanısı ile ilișkili ICD10 tanı kodları ile bașvuru olduğu belirlenmiștir. Atak hızı \%9,2'dir. Salgın incelemesinde 112 olası vakanın \%65'inin kontrollerin ise \%50'sinin musluk suyu içtiği (ORadj=1,9; \%95 GA: 1,1-3,5), buna karșılık vakaların \%39'unun kontrollerin ise \%54'ünün șișe suyu içtikleri (ORadj=0.51, \%95 GA: 0.29-0.90) belirlenmiștir. Toplanan 33 gaita örneğinin 27'sinde kültür sonucu S. sonnei, değișik noktalardan alınan 52 su örneğinin 18'inde total koliform (47-500) ve dört'ünde Escherichia coli (520) tespit edilmiștir. Çevresel incelemede, su deposunun yakınlarında kırık su borusu tespit edilmiștir.

Sonuç: Bu geniș çaplı salgın, kontamine musluk suyunun içilmesine bağlı büyük bir $S$. sonnei salgınıdır. Su șebeke sisteminin incelenmesi ve tamir edilmesi sağlanmıștır.

Anahtar Kelimeler: Shigella sonnei, salgın, içme suyu, vaka-kontrol çalıșması

\section{INTRODUCTION}

Shigellosis is a gastrointestinal infection by Shigella spp. characterized by symptoms such as watery, mucous, or bloody, diarrhoea, fewer, abdominal pain and tenesmus $(1,2)$. The causative agent, Shigella spp., consisted of four serogroups; $S$. disanteriae (Serogroup A), S. flexneri (Serogroup B), S. boydii (Serogroup C), and S. sonnei (Serogroup D). S. sonnei is predominant in industrialized countries and causes the mildest disease $(3,4)$. Shigellosis is a significant public health problem in developing countries where it remains a major cause of diarrhoea-related morbidity and mortality, especially among children $(5,6)$. The disease spreads more easily in places with insufficient personal hygiene and sanitation. Shigella spp. have very low infectious dose; for some Shigella subspecies the infectious dose could be as low as fewer than 10 organisms (4,7-
9). In many parts of the world, S. sonnei is a common agent of food- and water-borne gastrointestinal diseases and dysentery. Shigellosis due to $S$. sonnei is more frequent in industrialized countries $(3,5,10)$. In Turkey, it is revealed that shigella gastroenteritis is common and, mainly caused by S. sonnei (11-13).

On 24 September 2012, an increase in gastroenteritis cases in Terme City, Samsun Province was reported to the Public Health Institution of Turkey. Terme City is a small town on the Coast of the Black Sea, with a population of 73094 (including 31163 living in the city centre and 41931 living in villages and municipalities population). We conducted an investigation to determine the agent, cause, and mode of transmission of this outbreak. 


\section{MATERIAL and METHOD}

\section{Case definition}

In this investigation we defined a suspected case as diagnosis during 24-26 September 2012 at Terme Hospital of gastroenteritis-related ICD-10 codes (i.e., A04.9-Bacterial intestinal infection; unspecified; A09 - Infectious gastroenteritis and colitis, unspecified; K52 - Non-infectious gastroenteritis; and R11 - Nausea or vomiting) in a resident of Terme City, Samsun Province. A probable case was a suspected case with onset of diarrhoea ( $\geq 3 /$ day) or vomiting plus $\geq 2$ of the following symptoms: abdominal pain, nausea, perceived fever. We reviewed medical records of patients who sought care at local hospitals during 2426 September 2012 to find the cases.

\section{Selection of cases and controls}

In this case-control investigation, we randomly selected 130 suspected cases and 130 asymptomatic neighbourhood controls. Controls were selected among the household members in the house on the right-hand side of the cases' house-matched by age group $(0,1-4,5-9, \ldots \geq 65$ years). Trained staff from the local public health directorate used a questionnaire to collect the cases and controls demographic information, symptoms, hospital visit, medication, and risk factors such as water and food consumption. Our analysis was restricted to 112 probable cases and the 112 matched controls.

\section{Microbiological studies}

We inspected the water system of the city, and collected water samples from different points in the system for microbiological analysis. We cultured the water samples to identify common bacterial pathogens (including total coliform, E. coli, Clostridium perfiringens). Viral pathogens in water cannot be tested in Turkey. We also collected cases' stool specimens and used PCR (polymerase chain reaction) to identify common viral pathogens (including rotavirus, adenovirus, norovirus, astrovirus) and common bacterial pathogens (including Salmonella, Shigella spp. and E. colio 157 Vibrio cholerae 01 and 0139, Campylobacter spp., Aeromonas spp., Entamoeba histolytica, Giardia and Cryptosporidium). We also used Enzyme-Linked Immunosorbent Assay (ELISA), Direct Fluorescent Antibody (DFA) to identify common parasites (including Giardia, Cryptosporidium, Entamoeba histolytica) in the stool specimens.

\section{Statistical analysis}

The statistical analysis was carried out using the SPSS statistical program. Categorical variables were presented as percentages. Conditional logistic regression model analysis was used to determine the risk factors and to control for confounding. Sex, tap water and bottled water were included in the model. Statistical significance level was determined as $p<$ 0.05 .

The research was conducted according to the principles of the Declaration of Helsinki.

\section{RESULTS}

Evaluation of data collected from hospitals showed that, compared with September 2011, the number of patients with gastroenteritis-related ICD-10 codes increased sharply on 24 September 2012, peaked on 26 September, and sharply declined afterwards (Figure 1). In total 4239 outpatient visits were made to the healthcare facilities (hospitals, family physician centers in total) in the city during 25 September-01 October. A total of 2825 outpatient visits occurred in the city during 24-30 September 2012, compared with 1010 visits during the same time period in 2011. A total of 52 patients were hospitalized in Terme during 24 September - 01 October.

The overall attack rate was $9.2 \%$ in the downtown. The different districts in the city had similar attack rates, ranging from $8 \%-12 \%$. All age groups were affected by the disease; the 5-9-year age-group had the highest attack rate (18.7\%) (Figure 2). The attack rate was similar in males (4.8\%) and females (5.3\%). 


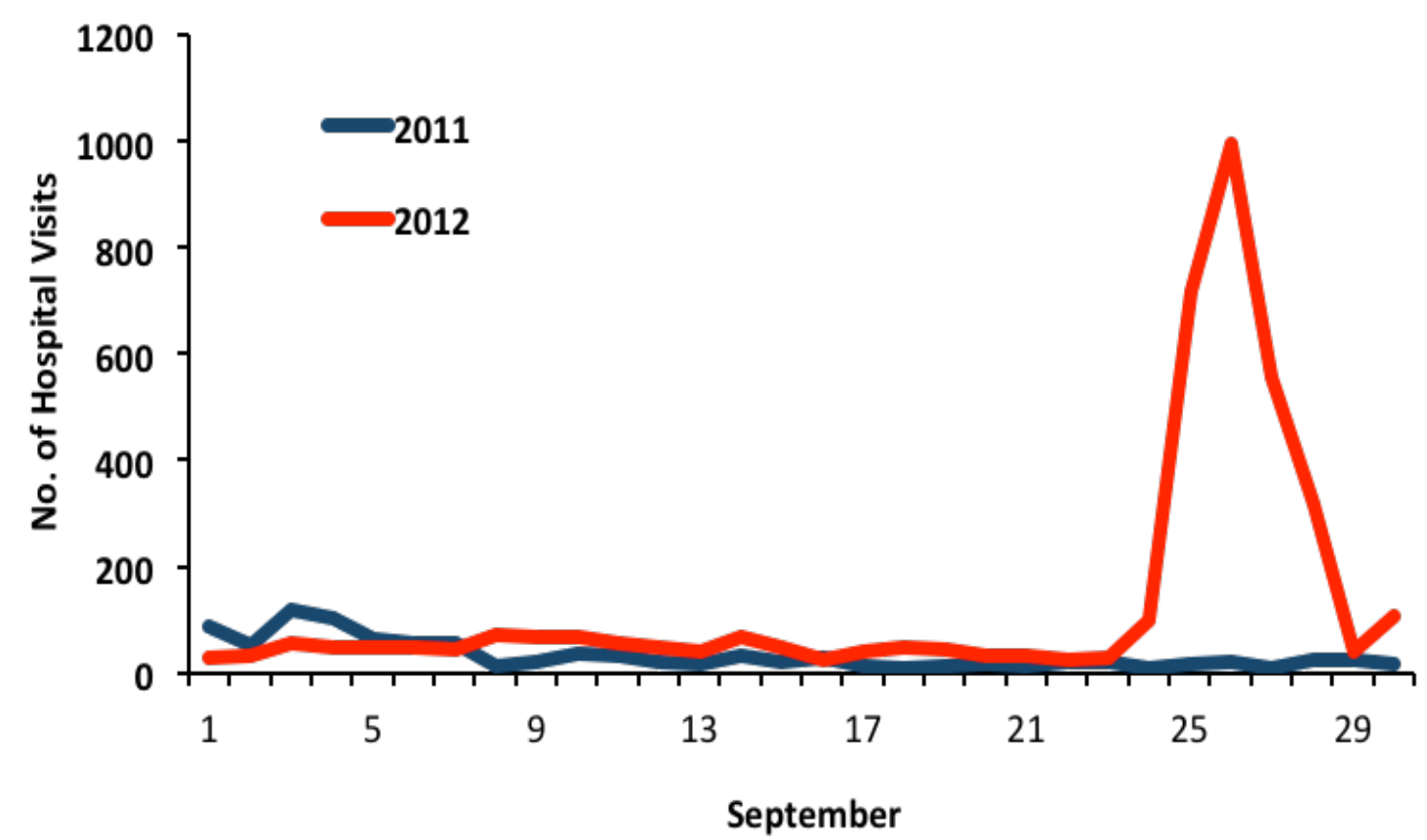

Figure 1. Number of hospital outpatient visits due to acute gastroenteritis (ICD 10:A09, A04.9, R11, K52) in September, 2011 vs. 2012: Terme District, Samsun province, Turkey

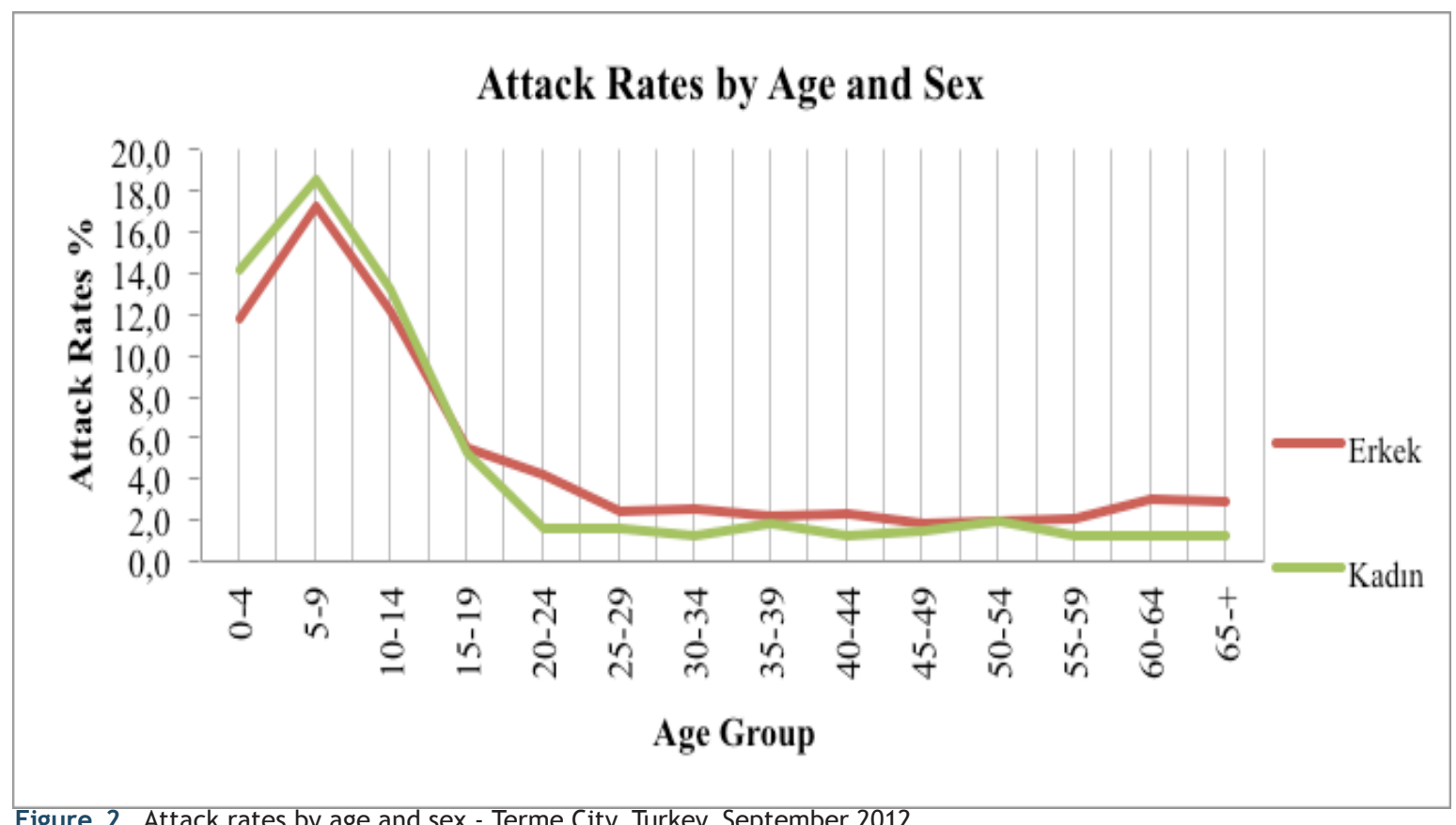

Figure 2. Attack rates by age and sex - Terme City, Turkey, September 2012 
Of the 112 probable cases in the case-control study, common symptoms included diarrhoea, fever, abdominal pain, nausea, and vomiting (Table 1). Cases and controls were compatible with respect to age- and sex-distribution. When we investigated the water that the cases and controls drank during 1824 September 2012 (one week before the outbreak occurred), drinking tap water was associated with a two-fold rise in the odds of being ill, compared to bottle water, after controlling for sex using conditional logistic regression (ORadj=2.0, 95\% Cl: 1.2-3.6) (Table 2 ). We also investigated potential associations with food items and found no association.

A total of 33 stool samples were taken from the suspected cases. S. sonnei was positive in 27 samples by bacterial culture. Of the 52 water samples collected from different points in the drinking water distribution system, total coliform was found in 18 samples (range: 47-500 colony forming units); E. coli was found in 4 samples (range: 5-20). Twenty percent of peripheral water samples had unsatisfactory chlorine levels (<0,2 ppm).

During the environmental investigation, we inspected the drinking water distribution system. We saw a recently broken water pipe; although the pipe had been repaired, the repair work was not completed appropriately; a puddle of water could be seen next to the repaired area (Figure 3).

Table 1. Symptoms of 112 probable cases during the outbreak of Shigellosis - Terme City, Samsun Province, Turkey

\begin{tabular}{lcc}
\hline Symptom & $\mathbf{n}$ & $\%$ \\
\hline Diarrhoea & 112 & 100.0 \\
Fewer & 108 & 96.4 \\
Abdominal pain & 104 & 92.9 \\
Nausea & 97 & 86.6 \\
Vomiting & 90 & 80.4 \\
\hline
\end{tabular}

Table 2. Risk of Shigellosis infection by types of drinking water Terme City, Turkey September 2012

\begin{tabular}{|c|c|c|c|c|c|c|c|}
\hline \multirow{2}{*}{ Types of drinking water } & \multicolumn{2}{|c|}{ Cases } & \multicolumn{2}{|c|}{ Controls } & \multicolumn{2}{|c|}{ Total } & \multirow{2}{*}{$\begin{array}{c}\text { OR }_{\mathrm{adj}^{*}} \\
(95 \% \mathrm{Cl})\end{array}$} \\
\hline & $\mathrm{n}$ & $\%$ & $\mathrm{n}$ & $\%$ & $\mathrm{n}$ & $\%$ & \\
\hline Only bottled water & 34 & 30.9 & 52 & 46.4 & 86 & 38.7 & 1 \\
\hline Tap and bottled water & 12 & 10.9 & 11 & 9.8 & 23 & 10.4 & $1.7(0.7-4.3)$ \\
\hline Only tap water & 64 & 58.2 & 49 & 43.8 & 113 & 50.9 & $2.0(1.2-3.6)$ \\
\hline Total & 110 & 49.5 & 112 & 50.5 & 222 & 100.0 & \\
\hline
\end{tabular}

${ }^{*}$ Controlled for sex 


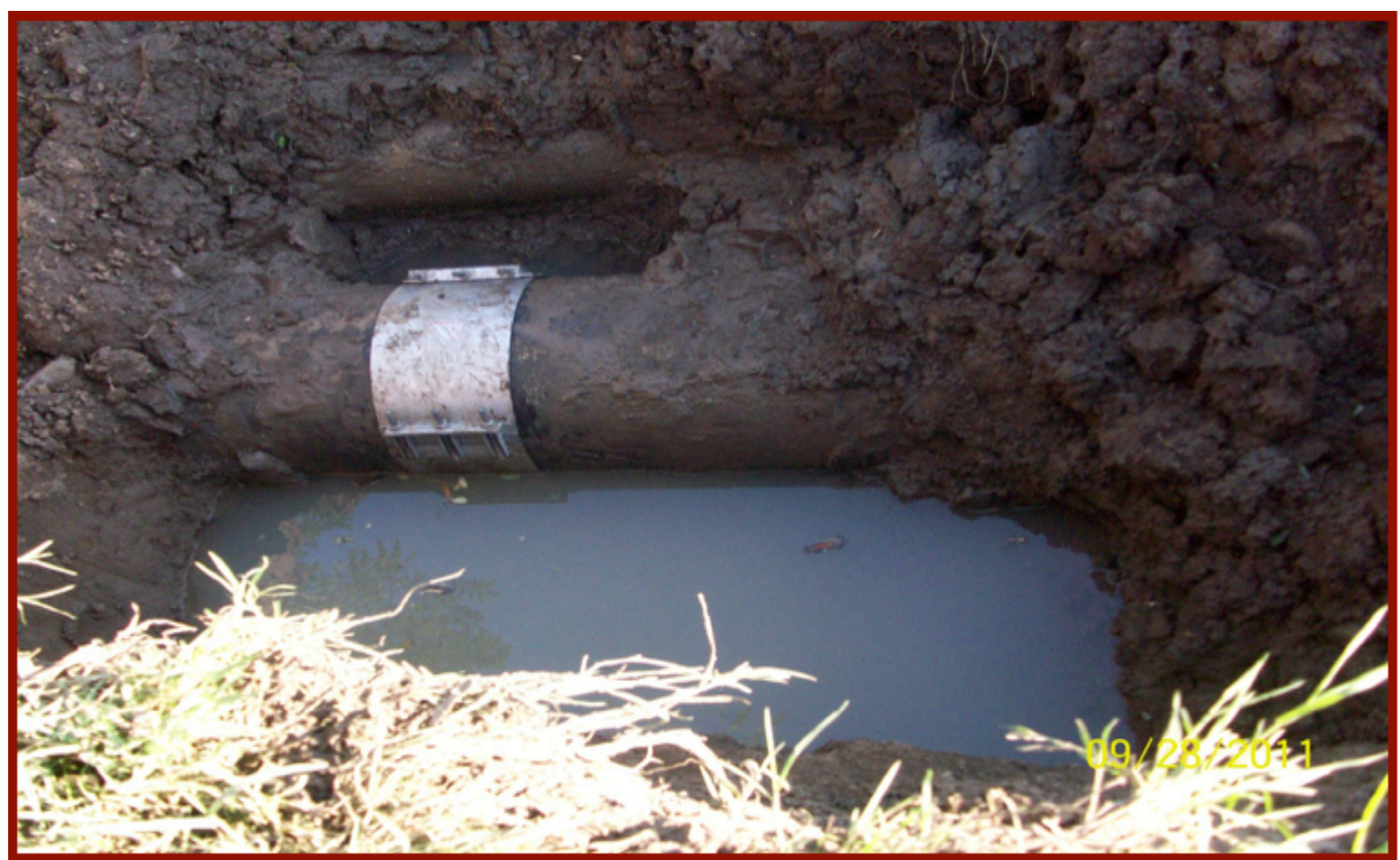

Figure 3. Leaked water from a broken drinking-water pipe was found during the outbreak of Shigellosis sonnei - Terme City, Turkey, September 2012

\section{DISCUSSION}

During 24 September-01 October 2012, a sharp increase in the number of gastroenteritis patients occurred in Terme City, Samsun Province, Turkey, affecting more than one thousand residents of the city. Epidemiologic, laboratory investigation and environmental investigations showed that this was an outbreak of $S$. sonnei caused by drinking contaminated tap-water. Recent water pipe work likely had caused the water contamination.

S. sonnei is a common cause of bacillary dysentery in many countries. There are many potential sources of an outbreak due to $S$. sonnei (14). Drinking water associated outbreaks have been documented in the US, Europe and elsewhere (14-17).

Shigella is an exclusively human pathogen; therefore, the contamination of the tap-water must come from the sewage system $(4,18,19)$. Because Shigella has a very low infectious dose, waterborne outbreaks can easily occur when the drinking water source is contaminated by sewage $(8,14,17)$. This epidemic curve indicated that this outbreak was caused by a point-source exposure. The sudden increase and sudden decline in the case counts during this outbreak indicated that this outbreak was due to a short time sewage contamination of the tap-water system (20).

The overall attack rate was $9.2 \%$ in the city. In some studies, similar attack rates have been reported $(6,14)$. In this outbreak, the attack rate was higher in children than in adults. This is consistent with previously published literature showing that outbreaks of $S$. sonnei infections commonly occur in child and young adults (5, 21-23). An investigation of a waterborne outbreak in Switzerland showed that 
the attack rate was $95 \%$ in the $0-7$ year age group, $96 \%$ in the $8-16$ year age group, and $81 \%$ in persons aged $\geq 16$ years (21). Another investigation of a waterborne outbreak in northern Israel showed that most of those affected were children under 15 years of age (22). An analysis of four outbreaks in different regions of Greece showed that the attack rate was 5-10 times higher in children and young adults than in adults (6). The higher attack rate in children is due to the fact that young children lack the immunity against Shigella which increases with age $(6,14)$. Previous investigations of outbreaks caused by $S$. sonnei in Turkey also showed that children were more likely to be affected (24).

Drinking water comes from lakes, rivers, streams or underground sources. These sources of water are linked in a watershed through the water cycle. Drinking water sources, especially the surface water sources can be easily contaminated, causing major and costly problems that are sometimes extremely difficult to correct. All efforts should be made to identify possible pollution sources and to ensure implementation of appropriate strategies and plans for water source protection $(25,26)$.

Our study has two major limitations. We were unable to identify Shigella in water samples. Identifying the agent in water samples is difficult because detection techniques generally used can have a relatively low sensitivity and reliability; therefore, total coliform bacteria and $E$. coli in water samples serve as surrogate indicators of water contamination by sewage $(5,19,21,27)$. Although we identified an inappropriately repaired pipe, no sewage tank was near the location; therefore, we were unable to determine exactly how the tap-water system was contaminated by sewage.

In conclusion, this large outbreak of S. sonnei infection was likely caused by contamination of tapwater with sewage. We recommended that the tapwater treatment system be thoroughly inspected and repaired, and the chlorine levels in the tap-water be regularly monitored. Based on our recommendation, the public health directorate in Terme City installed a new chlorination device to chlorinate the tapwater regularly, fixed the broken pipe, and started to regularly and frequently monitor the chlorine levels.

\section{REFERENCES}

1. Pickering LK, Baker JC, Long SS, MCMillian JA. Red Book :2006 Report of the Committee on Infectious Diseases American Academy of Pediatrics 1. 27th ed. Elk Grove Village, II, Sigma Publishing. 2006.

2. Heymann DL. Control of communicable diseases manual. American Public Health Association. 2008.

3. Nicolas X, Granier H, Le Guen P. Shigellosis or bacillary dysentery, La Presse Médicale, 2007; 36: 1606-1618.

4. Lee JC, Jeong YS, Oh JY, Kang HY, Kim KH, Kim J et al. Epidemiology of shigellosis in Korea. J Bacteriol Virology, 2006; 36: 41-49.
5. Arias C, Sala MR, Dominguez A, Bartolome R, Benavente A, Veciana P et al. Waterborne epidemic outbreak of Shigella sonnei gastroenteritis in Santa Maria de Palautordera, Catalonia, Spain, Epidemiol Infect, 2006; 134: 598-604.

6. Koutsotoli AD, Papassava ME, Maipa VE, Alamanos YP. Comparing shigella waterborne outbreaks in four different areas in Greece: common features and differences. Epidemiol Infect, 2006; 134: 157-162.

7. Kothary MH, Babu US. Infective dose of foodborne pathogens in volunteers: a review, J Food Safety, 2001; 2: 49-68. 
8. Sur D, Ramamurthy T, Deen J, Bhattacharya SK. Shigellosis: challenges \& management issues. Indian J Med Res, 2004; 120: 454-462.

9. Gutiérrez GI, Naranjo M, Forier A, Hendricks $\mathrm{R}$, Schrijver $\mathrm{KDE}$, Bertrand $\mathrm{S}$, et al. Shigellosis outbreak linked to canteen-food consumption in a public institution: a matched case-control study, Epidemiol Infect, 2011; 139: 1956-1964.

10. Guzman-Herrador, BR, Nilsen E, Cudjoe KS, Jensvoll L, Kwamme JM, Lindegard Aanstad A, et al. Shigella sonnei outbreak traced to imported basil-the importance of good typing tools and produce traceability systems, Norway, 2011. Euro Surveill, 2013; 18:49

11. Pullukçu H, Aydemir Ş, Sipahi OR, Yamazhan T, Tünger A. Species distribution and antibacterial resistance patterns of 439 shigella spp. strains isolated from stool cultures between 1999-2006. ANKEM, 2007; 21(3): 137-141.

12. Çelik C, Bakıcı MZ, Gözel MG, Dayı F, Kaygusuz R. Shigella species and antibiotic resistance distributions isolated from fecal samples between 2002-2011. ANKEM, 2012; 26: 143-147.

13. Kuzucu C, Baktır E, Acar N. Antibiotic susceptibilities of salmonella and shigella strains isolated between 1998-1999. Turkish Bulletin of Hygiene and Experimental Biology, 2001; 58(1): 11-14.

14. Alamanos Y, Maipa V, Levidiotou S, Gessouli E. A community waterborne outbreak of gastro-enteritis attributed to Shigella sonnei. Epidemiol Infect, 2000; 12: 499-503.

15. Levy DA, Bens MS, Craun GF, Calderon RL. Surveillance for waterborne-disease outbreaks -United States, 1995-1996. MMWR CDC Surveill Summ, 1998; 47: 1-34.

16. Black RE, Craun GF, Blake PA. Epidemiology of common-source outbreaks of shigellosis in the United States, 1961-1975. Am J Epidemiol,1978; 108: 47-52.

17. Arnell B, Bennett J, Chehey R, Greenblatt J. Shigella sonnei outbreak associated with contaminated drinking water--Island Park, Idaho, August 1995. MMWR Morb Mortal Wkly Rep, 1996; 45: 229-231.
18. Lampel KA, Shigella species. In: Lampel KA., Khald SA, Cahill SM, (eds.). Bad Bug Book. Foodborne Pathogenic Microorganisms and Natural Toxins. Vol.2. 2012;22-25. Available from:

https: / / www.fda.gov/downloads/food/foodsafety/foodborneillness/foodborneillnessfoodbornepathogensnaturaltoxins/badbugbook/ucm297627. pdf, [Cited at: 24.09.2018 ].

19. World Health Organization. Guidelines for Drinking Water Quality Incorporating 1st and 2nd Addenda, vol.1, Recommendations 3rd edition, volume 2, Health Criteria and other Supporting Information. WHO 2008. Available from: URL: http://www.who. int/water_sanitation_health/dwq/fulltext.pdf, [Cited at: 24.09.2018].

20. Akın L. Control of Water and Foodborne Diseases. In: Güler Ç, Akın L, (eds.). Public Health Basic Information. Volume 3, 2nd Edition. Hacettepe University, 2012; 1388-1403.

21. Maurer AM, Sturchler D. A waterborne outbreak of small round structured virus, campylobacter and shigella co-infections in la Neuveville, Switzerland, 1998. Epidemiol Infect, 2000; 12: 325-332.

22. Egoz N, Shmilovitz M, Kretzer B, Lucian M, Porat V, Raz R. An outbreak of shigella sonnei infection due to contamination of a municipal water supply in northern Israel. J Infect, 1991; 22(1): 87-93.

23. Alcoba-Flórez J, Pérz-Roth E, González-Linares S, Méndez-Alvarez S. Outbreak of shigella sonnei in a rural hotel in la Gomera, Canary Islands, Spain. Int Microbiol Off J Span Soc Microbiol, 2005; 8(2): 133-136.

24. Yalçın AN, Turhan Ö. Evaluation of patients with acute diarrhea. J Int Med, 2004; 11 (4): 182-193.

25. Safe Drinking Water Foundation. Source Water Protection. Source Water Protection Fact Sheet. at https://www.safewater.org/factsheets-1/2017/1/23/source-water-protection, Access date: 24.09.2018).

26. WHO. Optimizing regulatory frameworks for safe and clean drinking-water. Available from: http:// www.who.int/water_sanitation_health/dwq/ sheet4.pdf, (Access date: 24.09.2018).

27. Samonis G, Elting L, Skoulika E, Maraki S, Tselentis Y. An outbreak of diarrhoeal disease attributed to shigella sonnei. Epidemiol Infect, 1994; 112: 23545. 